\title{
In Search of the Postmodern Utopia: Ben Okri’s In Arcadia
}

\section{Alistair Fox, University of Otago}

As one of the early reviewers of Ben Okri's most recent novel —In Arcadia (2002) affirmed, 'you cannot fault Okri for confronting the big issues and asking questions of our secular age that few of his contemporaries have the innocence or bravery to attempt' (Adams 2002). Beyond conceding that, however, most commentators have slammed the novel as inflated in its philosophical pretensions, and defective as a work of literary art. Writing in The Independent, Helen Brown concluded that 'In Arcadia reads like the ramblings of a stoned sixth former' (Brown 2002), sentiments echoed by another group of readers who labelled the work 'so much pseudo-philosophical piffle’ (http://www.calderdale.gov.uk). On another tack, Jeremy Treglown lamented that the novel 'has no narrative tension and the characters are ciphers' (Treglown 2002), while another reviewer criticized it for having 'a thin under-developed plot and even thinner characters imposed on it,' judging that Okri has presented 'a sloppy, poorly written novel which starts out by accusing the reader of being too stupid to understand the grand plan of his work, and ends with more incomprehensible speculation on the nature of life, reducing his characters to mere inscriptions' (Ball 2002). Critics who admired Okri’s earlier novel, The Famished Road (1992), for which he won the Booker Prize, almost universally see In Arcadia as a sad falling away from that accomplishment: 'In Arcadia is the antithesis of that book. Where The Famished Road was African, expansive and generous in spirit, In Arcadia is European, thin and mean in temperament' (Hickling 2002). My contention in this essay is that readers who interpret the novel this way have missed the point, largely because they have failed to understand the tradition within which Okri has taken pains explicitly to locate his work. Having done so, they then read it as if it were an exercise in another type of novelistic genre, and hence miss the deeper reflections on the 
human condition that In Arcadia has to offer. These, in turn, can only be fully understood through the lens of a particular reading formation, given the large number of significant intertexts that are invoked in the course of the novel. When the intertexual dimensions of In Arcadia are acknowledged, it becomes clear that Okriin contrast to what he was attempting in The Famished Road and his other works set in Nigeria-has attempted no less a task that to reinterpret the perennial human aspiration to seek Utopia (imagined poetically, following Virgil, Sannazaro, and others as 'Arcadia') in the light of the destruction of determinate ethical and religious certainties wrought by the influence of postmodernism. As such, In Arcadia is a work that situates itself squarely in one of the most durable intellectual traditions of Western thought, from Plato and St Augustine through Virgil, Thomas More, and beyond, rather than in the more specific locale of postcolonial Nigeria, or in the reading formation of popular fiction. It is not merely more ambitious than anything Okri has written previously, but also presented as a work that challenges the reader to consider Okri's reflections in relation to what others, in different contexts, have propounded with regard to some of the most significant issues that confront humankind. It is little wonder, then, that commentators who may have been expecting a different kind of novel have found difficulty in acknowledging what this extraordinarily innovative exercise in fictive philosophy has attempted to communicate.

1

What, then, are the generic elements that set In Arcadia apart from what its reviewers may have been expecting? In the course of the work, Okri represents and interprets the condition of the contemporary world, which is found to be unsatisfactory, and contrasts it with an alternative condition that is viewed as being an antidote to the first one. It is thus a classic exercise in the speculative literary utopia represented by such works as Thomas More’s Utopia (1516), or Francis Bacon’s New Atlantis (1626), both of which are alluded to in Okri's text (Okri 2002, 18). Like those earlier exercises in the genre, In Arcadia presents a literal journey that suggests a metaphorical one. More’s speculative traveller, Raphael Hythlodaeus, and Bacon's narrative persona both travel to an island in the South Sea. Similarly, Okri depicts his narrator and his companions, the members of a film-crew making a documentary, as setting off on a journey to a literal location: Arcadia in the Peloponnese. Okri has 
based this journey on a real-life trip he made from London to Arcadia in 1996 to present a film in the BBC's 'Great Train Journeys' series. In all three cases, the journey is dressed up with the trappings of verisimilitude, but, as Okri affirmed in an interview with Judith Palmer given in 2002, 'the book inhabits a real journey to say something quite parallel, in the same way that a dream is parallel to a life, and all the possibilities of our lives run parallel to one another' (Palmer 2002). As an exercise in the utopian genre, the novel is much more than it seems.

Indeed, In Arcadia is more than simply a literary utopia. In constructing the fictive vehicle for his philosophical speculations, Okri blends the utopian genre with a number of other intertexts and fictive modes that deepen the significance of the representation at the symbolic level. The thematic framework for the whole book is provided through allusions to Dante's La divina commedia and Milton's Paradise Lost which allow Okri to invoke the idea of a paradise lost, and a paradise to be regained. Following Dante, Okri describes the modern world as an 'inferno,' in which men and women are 'lost in the dark woods of reality' (Okri 2002, 5, 36). Following Milton, he evokes the idea of a 'Garden of Eden' that has been irretrievable lost, but to which we long to return: 'We had all lost something, and lost it a long time ago, and didn't stand any chance of finding it again. We lost it somewhere before childhood began. Maybe our parents lost it for us, maybe we never had it, but we sure as hell didn't feel that we could ever find it again, not in this world or the next' (6). The appeal to Dante and Milton allows Okri to represent the literal journey depicted in his novel as an archetypal one-representing an attempt to escape from the inferno, through purgatory, to a recovered 'true' paradise that transcends the sordid and debased imperfections of the fallen world: 'When everything is said and done, given the anxiety and stress, the nightmare in which we stewed, escape is what it was all about. We would have escaped from life if we'd had the courage, but we were all cowards...' (6). By the end of In Arcadia, Lao, the narrator, along with several of the other characters, have found their recovered paradise, but it is, as I shall argue, conceived as one that is invested with a postmodern distinctiveness in comparison with its antecedents.

The third great literary tradition upon which Okri draws is that of the Arcadian earthly paradise, depicted by the Greek poet Theocritus and the Roman poet Virgil, and then 
later by poets writing in the pastoral tradition, especially during the Renaissance. Okri himself succinctly summarizes the main lineaments of this tradition:

Virgil refined the pastoral form, and raised the potent beauty and ambiguity of the Arcadian notion till it became, in his Eclogues, a landscape of shepherds, a refuge for exiles, a place of disordered passions, a place of dispossession, a realm of love poetry, of singing matches, of an encounter with the tomb of the famous and beautiful Daphnis. It also became a setting for one of the most mysterious and messianic poems in literature, a terrain for the celebration of a god, a territory for the praise of the powerful, and a place of departure.

In short, Virgil transformed Arcadia into a landscape of the human spirit, where love, history, politics, religion, work, poetry, and power converge and live. With Virgil, Arcadia became the seed of an ideal, a dream, and a lyric meditation on the mystery of creation and creativity (207).

Within Okri's novel, this Arcadian vision is used to construct the image of the recovered paradise that Lao comes to realize is available to human beings even while they are imprisoned within the labyrinth of this world. It resides in the ability of the mind to 'develop wings and soar,' and it is the creativity of art that allows this to happen - in the 'painting of the mind, where you first create the complete form of a thing or dream or desire and feed it deep into the spirit's factory for the production of reality’ (Okri 2002, 209, 189). This creative process, which, in Okri's vision, constitutes the salvation for humankind, is figured forth in the novel by his evocation of the image of the Arcadian earthly paradise.

To the topoi drawn from these three major European literary traditions, Okri also adds elements of the magic realism he had used earlier in such novels as The Famished Road and Songs of Enchantment-particularly in the suggestion of a parallel mythical universe - combined with narrative techniques derived from the African oral tradition, including poetic evocations and lyrical 'intuitions'. The mythical journey accomplished by the narrator, Lao, also bears some resemblance to that undertaken by the abiku spirit-child in The Famished Road. Even though some readers have felt betrayed by Okri's apparent abandonment of his earlier Nigerian preoccupations in In Arcadia, an attentive reading of it will detect the blending of earlier postcolonial attributes with some of the most persistent themes in the Western literary tradition. It is this attempt to achieve an aesthetic and signifying 'hybridity' that gives the novel its very distinctive character, that commentators have found so perplexing. 
To summarize, then, the simultaneous presence of elements from these three great European literary traditions, combined with elements from the African cultural tradition, gives In Arcadia a great depth of signifying resonance. The purpose of this particularly complex amalgam of the European and African cultural traditions is to undertake a journey that is speculative and mythical as well as literal and real, designed to find a way of responding to the postmodern condition of humankind that can provide the individual with an alternative to despair. It remains now to trace how the fiction works to accomplish this extremely ambitious aspiration.

In his interview with Judith Palmer, referring to In Arcadia, Okri declared that 'We inhabit a middle track we call our lives, but on either side Arcadia and Death are also running concurrently, and we are never far away from either plane. The book tries to encompass all these three layers' (Palmer 2002). The paradigm Okri offers here suggests a useful way of approaching the novel's complexities. In the first instance, the notion of our lives as a 'middle track' is literally figured forth in the railway track upon which the Eurostar train rolls on its journey as it carries Lao and the film-crew towards the Peloponnese, where they intend to make a documentary film on Arcadia. The reader is soon made aware that 'within our journey there was another secret journey, a cryptic journey,' that involves 'a dying of the old self; a birth of something new and fearless and bright and strange' (Okri 2002, 17, 32). Many aspects of the literal train journey are invested with symbolic significance. The crowding of people at Waterloo Station where the journey begins was 'the crowding of anxiety and stress,' on the part of voyagers who had all 'lost something.' Similarly, the baggage they had brought with them represents their psychic baggage: 'They had brought their ghosts with them, had brought their fears, their failures, the problems that had haunted their fathers, the nightmares that troubled their mothers...We never travel alone. An extended family of unacknowledged monsters follow us. And they don't die with us; they become part of our children' $(35,36)$. It is significant that on this journey 'there are no destinations. Destinations are illusions' (49). That is why Lao and the filmcrew never actually arrive at the literal geographical location of Arcadia—which, instead of indicating that Okri simply ran out of steam, as most of his reviewers imply, underlines the philosophical point that he is trying to make. 
The philosophical point is informed by Okri's awareness of the radical shift in consciousness wrought by poststructuralist thinking in the later twentieth century-a shift that has produced the age of postmodernism. The effects of this intellectual revolution, in Okri's view, have rendered solutions propounded by earlier traditions less easily attainable for people living in the new millennium. The dilemma of the postmodern subject is depicted in the condition of the characters before they set out on their journey of self-discovery; they are living in a world that has become characterized by fragmentation, loss of identity, dislocation, and the delegitimization of the determinate belief and value systems to which human beings used to appeal. As Okri puts it, this is a world marked by a 'welter of meanings and signs and auguries,' in which the individual subject has been left with a 'loss of belief' and a sense of an 'empty universe where the mind spins in uncertainty and repressed terror.' It is 'a life lived at speed, with many gaps in perceived reality' (Okri 2002, 120, 119). This is a world that is far removed from the optimistic one posited by modernism as described, for example, by Marshall Berman:

To be modern is to find ourselves in an environment that promises us adventure, power, joy, growth, transformation of ourselves and the world—and, at the same time, that threatens to destroy everything we have, everything we know, everything we are . . . Modernity can be said to unite mankind. (Berman 1983, 15)

Instead, it reflects the breakdown of modernism proper that Berman sees as marking its third and final historical phase-which is one reason why Okri is more properly regarded as a postmodernist, rather than modernist, writer:

.....as the modern public expands, it shatters into a multitude of fragments speaking incommensurable private languages; the idea of modernity, conceived in numerous fragmentary ways, loses much of its vividness, resonance and depth, and loses its capacity to organize and give meaning to people's lives. As a result of this, we find ourselves today in the midst of a modern age that has lost touch with the roots of its own modernity (Berman 1983, 17).

In short, the world Okri describes is one in which heterogeneity has become so expanded that people's existence is defined, as Jim Collins has put it, by 'competitive interpellation,' in which the subject is 'bombarded by competing messages simultaneously,' necessitating discursive practices that lead to fragmentation and decentred subjectivity (Collins 1989, 143). In the social sphere, postmodernist thinking has assumed that 'culture does not have one center or no center, but multiple simultaneous centers,' with resulting configurations that 'do not form a planned or well-managed pluralism, but a discontinuous, conflicted pluralism, creating tension- 
filled environments that have enormous impact on the construction of both representations and the subjects that interact with them' (27). To Okri, echoing Dante, this contemporary world comprises nightmarish 'dark woods' in which people have become lost (36). I am not going to enter into the debate about whether postmodernism is distinct from modernism, or whether it is merely the detritus of a failed modernist vision. ${ }^{1}$ As far as the present discussion is concerned, the point is that whether one sees the characteristics of the world described in Okri's novel as the consequences of the breakdown of the modernist project, as Berman does, or as the effects of a postructuralist valorization of heterogeneity, as Collins does, the phenomenon itself is the same-and this is the condition from which Lao and his crew are seeking to escape: 'the only thing for us was the journey, the escape, the way out' (6).

At the same time as Okri develops this depiction of the postmodern dilemma as the dominant reality of the 'middle track' his characters inhabit, he also intimates the parallel presence of Death on this journey in a variety of ways. On the platform at Waterloo Station, for example, it seems to the narrator as if 'Death wandered everywhere.' Death is personified: 'As we collected our luggage, death came and helped everyone like a friendly porter.' Even the train itself is identified with death: 'Death is the train on which we travel, the bus on which we journey, the car that speeds us there, whether we arrive safely or not. Death is the vehicle of the voyage...' (48-9). Perhaps the most powerful evocation of the idea of Death resides in the symbolism given to the passing of the train through the Channel tunnel: 'In tunnels we rehearse dying. Tunnels are a little death, a death with the senses wide awake, an open-eyed borderline between dying and living' (70). Death, in fact, is an omnipresent reality in this novel, even to the extent of being figured forth in Queen Marie Antoinette's quaint pastoral hamlet that Lao and Mistletoe visit at Versaillesa false Arcadia that 'concealed from her the guillotine that would chop off her head' (177). Its most arresting representation is contained in the climactic inscription on the tomb depicted in Poussin’s painting, Les Bergers d'Arcadie: 'Et in Arcadia ego’—_I too [i.e. Death] have lived in Arcadia’ (203-04).

\footnotetext{
${ }^{1}$ For the debate over modernism and postmodernism, see Eagleton 1986, Hutcheon 1989, and Jameson 1991.
} 
The effect of the repeated intimations of the presence of Death—which are designed to fill the reader with a sense of memento mori-is reinforced by references to another sinister figure, Malasso, who is never actually seen, but who is suspected of delivering the mysterious 'inscriptions,' or messages, that the characters receive in the course of the journey. Malasso, whose very name contains the root 'mal', conjures up the idea of malevolence and evil. He is described as a 'malign Prospero figure,' and thus constitutes a parodic antitype to the benign Prospero (whose name means literally 'I shall prosper,') encountered in Shakespeare's play The Tempest. Okri makes explicit the hints contained in Malasso's name when he suggests that Malasso is a character who serves as a personification to explain all the 'inexplicable mishaps, disasters, and tragedies' that befall men and women (Okri 2002, 25). In this guise, he stalks through the novel with a presence like that of an assassin. In another era, Malasso might have been depicted as Milton’s Satan, or More’s Antichrist; here, however, Okri shows him in his secularised, postmodern guise.

Just as Okri develops this powerful sense of Death running concurrently on one side of the 'middle track' of the lives of men and women, he takes equal pains to intimate the presence of Arcadia, in its deepest metaphorical sense, on the other. The first sign of it comes in the reference to the hidden 'treasures' in Arcadia to which the inscriptions the film crew is to follow will lead, and in the suggestions that Arcadia represents 'a sort of Garden of Eden, our lost universal childhood’ (5, 7). The nature of these treasures is intimated in many small instances, such as the description of the train-driver's little garden, which Lao and the crew go to visit in the seedy suburbs of Paris. Even though there 'was nothing particularly spectacular about the garden,' it moves Lao, because of the 'spirit of care and humility, of shaping beauty within life's chaos.' He sees 'the terracotta pots of flowers on empty wine barrels. He saw the forsythias, the apple tree on the left next to the gate, the wisteria on the front fence, and grape vines trailing from the railings. Lao marvelled at the variety of flowers and their cheerful intermingling.' There had been nothing there before, but, as the traindriver's wife explains 'with a gentle pride,' the love of her and her husband had transformed the urban sterility: 'Such was the way of the creative hand, flowering life where bare stones lay, domesticating barrenness, beautifying concrete' (126). Okri's handling of this episode turns it into a microcosm of what is possible as a result of the 
Arcadian creative impulse generally: it is a miniature Eden wrought through art in the midst of the wreckage of the modern world.

The potentiality symbolized by 'Arcadia' is also intimated in the development of the character of 'that crazy girl who fell in love with one of us,' and in so doing prevented the members of the film crew from needing to 'stew in hell till the end of time' (Okri 2002, 7). This girl turns out to be Mistletoe, a red-haired painter who, having begun a life 'in happiness,' fell into a 'love of rebellion', becoming 'misused by men,' and then 'disillusioned and disenchanted. Talents not developed early, lost on the way, wandering, beautiful, optimistic still, and lost.' The language here evokes the great myth of the fall from paradise recited in the poetry of Milton's Paradise Lost. There are hints that Mistletoe has replicated the falls of both Satan and Eve. But unlike Satan, however, she is able to follow Eve and Adam in the regaining of another paradise - by following 'the slow journey back, through art, to sanity' (80-1). Mistletoe plays a key part in Okri's novel because the pattern of her experience, combined with her emotional and intellectual responses to it, turns her into an exemplar of what is possible for the other characters, and of what they should imitate- even though some of them, notably Jute, refuse to do so. In this regard, the role of art in Mistletoe's life is all-important. It is seen when she alone, of all the other characters, remains unaffected by the sordidness of the Paris hotel in which they find themselves lodged:

Only Mistletoe was unaffected. The gloom provided her with dark shapes, the sense of failure with Hades-inspired images, and hunger fuelled the flight of her mind into a realm of enchantment. It was a realm she was able to enter at will because she had lived a life so rich with misery, mistakes and love that she had gradually found an art of creating pleasant places in her mind where colours are astonishing, where life sings, and where possibilities lurk behind all evil shapes. Unhappiness had taught her the art of happiness. And art had taught her the saving graces of escape into the enchanted countrysides of her mind (130-1).

This passage, in capturing the paradox that the kind of happiness which is attainable through the creative imagination is made possible by the experience of unhappiness, and even tragedy, foreshadows the epiphany that Lao, the main character, will have as he contemplates the Poussin masterpiece in the Louvre. Art, in fact, is depicted as the means by which humankind can regain paradise:

Painting is human love transcending human forgetfulness. 
There is painting of the mind, where you first create the complete form of a thing or dream or desire and feed it deep into the spirit's factory for the production of reality. Painting is the mirror of healing, the base of creativity, the spring-board of materialisation (189).

In Okri's summation, 'Painting is one of the most mysterious metaphors of Arcadia' (190).

As the film crew progress their journey on the 'middle track,' therefore, there are constant intimations of a parallel ‘Arcadian’ creative possibility that offers humankind a means of counteracting the negative potentialities of the other parallel death-driven alternative. In the final part of this essay, I shall track the extent to which the various characters succeed in perceiving the existence of this creative possibility, and then speculate on what it implies in the context of postmodernity.

What do the characters learn? The journey presents each with an opportunity to interpret the meaning of mysterious messages that are passed to them, and of inscriptions that they encounter. Messages and inscriptions have a key significance in this novel. According to Okri,

Every now and again life sends us little messages. The messages are meant for us alone. No one else can see them. No one else perceives them as messages. They may seem perfectly banal to the world, but to you, for whom they were intended, they have the force of revelation. Much of the failure and success of a life, much of the joy or suffering in a life, depends on being able to see these secret messages. And much of the magic, or tragedy of life depends on being able to decipher and interpret these messages (Okri 2002, 22).

In Lacanian terms, these messages arrive at the moment when the addressee becomes the addressee when he or she recognizes himself or herself as the addressee (Žižek 2001, 10-12). For Okri, however, these messages come from behind 'a mysterious veil that separates the living from the others. And this veil is made of perception'. The messages themselves 'come in daily life, in as many forms as there are ways of reading the world,' and are 'projected through this veil'. Similarly, 'inscriptions appear on the fabric of the world' (Okri 2002, 22-3).

In the course of the novel, various of the characters receive messages that appear to constitute a potential realisation that they are predisposed to have as a result of their prior experience and temperamental dispositions. For example, Jute, the accountant, is a humourless gorgon of moral rectitude, for whom work is her real Arcadia. When she receives her message she is too horrified by its contents to show it to anybody else, 
and ends up remaining trapped in a nightmare. Towards the end of the novel, she is described as being unable (literally and metaphorically) to 'get to the party,' because she 'was looking for her mother in the winter of her being and could not find her.' Soon, she finds herself 'a prisoner in the block of ice of her own being' (Okri 2002, 198). Jim (the director), by way of contrast, receives a message instructing him that the crew are to approach the train driver and conduct an interview with him at his house in the suburbs of Paris, and then to proceed to the Louvre. This message activates (or reflects) Jim's openness to discovering a deeper meaning in their journey than is apparent on the surface: 'For the first time, Jim sensed their journey was an arcane voyage, the interviews and places forming an inner script, a sacred script even. He felt that they were all unwitting parts of a sublime riddle, a mystical conundrum, a travelling cryptograph’ (75). Riley, the assistant camerawoman, receives a sinister message 'soaked in blood, or red ink,' which, even though she does not share it with the others, fills them with 'a sense of doom or of awe' which predisposes them to recognize the perversion of the Arcadian ideal in the false Arcadia of Versailles: 'death sang through the sublime vanity of it all,' and as Mistletoe comes to realize, 'Hades dwells in false Arcadias' (162, 169, 179).

All the messages received by the characters are associated with Malasso, and serve to activate an awareness of the characteristics of the modern world that impart to it a kind of death-in-life, and generate a desire to rectify it by seeking the place of true enchantment. The ability to get to that place of enchantment depends upon the ability of the characters to interpret the 'inscriptions' they encounter, and, above all, the literal inscription on the tomb within the Poussin painting in the Louvre that presents the most important, climactic inscription in the novel.

The idea of a tomb in Arcadia first appeared in Virgil's Eclogues $V$ when Mopsus, a shepherd, exhorts all shepherds to rear a tomb to Daphnis, who has been 'cruelly slain' (Virgil ll. 42ff in Smith, n.d.). In selecting his iconography, Poussin also drew upon Jacopo Sannazzaro's imitation of this topos in La Arcadia of 1504, in which the shepherd, Barcinio, describes the tomb of Phyllis, a nymph who refused to requite the love of his friend, Meliseo:

I will make thy tomb famous and renowned among these rustic folk. Shepherds shall come from the hills of Tuscany and Liguria to worship this corner of the world solely because thou hast 
dwelt here once. And they shall read on the beautiful square monument the inscription that chills my heart at all hours, that makes me strangle so much sorrow in my breast: 'She who always showed herself so haughty and rigid to Meliseo now lies entombed, meek and humble, in this cold stone'. (Sannazzaro 1952, 1l. 257-267).

In both these earlier literary versions, the idea of a tomb in Arcadia serves to intensify the pathos arising from the death of a lover, with a strong sense of 'carpe diem' - that is, that lovers should 'seize the day' before Death removes the possibility.

Okri sees a much deeper significance than that in Poussin's Les Bergers d'Arcadie. Lao, his narrative persona, identifies it as 'an open painting, impossible to decipher completely,' pointing to the fact that 'the beauty does not reside in the landscape, which is rocky and mostly bare,' but in 'the structure, the colours, the harmony of the lines of force in the painting, and in its mood.' It is unclear as to who is the 'I' alluded to in the inscription, 'Et in Arcadia ego,' and 'the shepherd who points forms the shape of a man with a scythe in his shadow' that serves to unsettle any possibility of indulging in Arcadian melancholy as a pleasurable gratification. The effect of this blending of harsh, incongruous elements is, in Lao/Okri's words, to fill the onlooker with peace, 'But within that peace it plants the seeds of restlessness, of unease, of subtle disturbance, like a meaningful dream not fully understood, filling your waking hours with question marks’ (Okri 2002, 203-6).

Indeed, of all the characters, it is Lao himself who is most affected by the painting, and when he views it, 'The message that had been sleeping within him since the beginning of the journey now awoke and sprang into life’ (Okri 2002, 206). What he realizes is that the painting 'gives the code for continual development in living, and in thinking,' in its 'complexity, its hope and its despair, its power and its humility' (203). Specifically, it emphasizes — through the presence of the tomb with its enigmatic inscription — that 'Arcadia and death are inextricably intertwined. Immortality and death are conjoined. Beauty and death are linked, happiness and death are coupled' (206). Moreover, there is no hint of transcendence in Poussin: the fact inscribed on the tomb-'I [Death] too lived in Arcadia'— 'is a labyrinth without any exit. It is closed.' Confronted with this reality, Lao decides 'That he would be among those who learn to live within the labyrinth, that he would join those who develop wings and soar' (209). 
This, then, is the climactic point towards which the metaphoric journey has been tending. There is no need for the novel to pursue the rest of the literal journey to the real geographical Arcadia, because the nature of the true Arcadia has already been revealed in this climactic epiphany that Lao experiences: induced by his contemplation of the great painting by Poussin that ponders the condition of existence of this nurturing myth of the human imagination.

When all the elements of this subtle fiction are viewed in their complex interrelations with one another, it is apparent that Ben Okri has made an important new contribution to the conceptualisation of Utopia. Utopia, for Okri, is a state of mind-a condition of activated responsiveness to, and engagement with, life that is made possible by the Arcadian vision that the creative imagination can construct. This vision is attained through art, which Okri views as 'a dream of perfection.' Even though it is 'many realms away from the reality,' this dream can nevertheless lead to redemption, because it replaces 'what we have lost in spirit' (Okri 2002, 165, 83). Okri's concept of Utopia, in fact, is very close to Kant's idea of Aufklärung (Enlightenment) as expounded by Michel Foucault (Foucault 1994, 303-19). In Foucault’s words, 'Aufklärung ...is neither a world era to which one belongs, nor an event whose signs are perceived, nor the dawning of an accomplishment. Kant defines Aufklärung in an almost entirely negative way, as an Ausgang, an “exit,” a “way out”.' This 'way out' is a process that releases us from the status of 'immaturity,' which is 'a certain state of our will which makes us accept someone else's authority to lead us in areas where the use of reason is called for.' Enlightenment, in Foucault's reading of Kant, is defined by 'a modification of the pre-existing relation linking will, authority, and the use of reason.' This means, in turn, that 'Enlightenment must be considered both as a process in which men participate collectively and as an act of courage to be accomplished personally. Men are at once elements and agents of a single process. They may be actors in the process to the extent that they participate in it; and the process occurs to the extent that men decide to be its voluntary actors' (305-06).

The Arcadian vision, in Okri's view, is an aestheticized version of Enlightenment as defined in Foucault's redaction of Kant. As such, it has the potential to ameliorate the 'anomie' and 'mass silent despair' of the modern world—-the world of: 
wars across nations. Refugees across borders. . . Families dying of starvation. . . . Environmental disasters everywhere. Pollution everywhere. . . . Emptiness and absence of religion. Humiliation and no sense of redemption. Just work and television and sex and entertainment. Loves that fail. Marriages that die. Hopes that perish with the onset of adulthood. Knowledge that drives away the freshness of innocent dreaming' (Okri 2002, 219-220).

The exterior world, in Okri's account, mirrors the condition of our being: 'So the cosmic illness, the anomie, the despair, the terror, the nausea, the emptiness are all within. We are the sickness. We harbour our own malaise, and then we project it onto the world.' Conversely, when we seek to shape the world in accordance with 'this better and juster dreaming' of Arcadia,' life can become 'a place of secular miracles,' where 'amazing things can be done in consciousness and in history' (Okri 2002, 2223). It is all relative, however. Even if the external world can never be perfected, the interior regeneration that is brought about by the dream of Arcadia is capable of leading the individual, within the range of his or her ability and will, to do 'little things' that make a difference (229). Although Okri does not develop the idea to any great extent, it is implied that the political and social well-being of a nation will be commensurate with the strength and depth of the Arcadian impulse as expressed in its art, since:

Civilisations are ... measured by their dreams, by their aspirations in stone, in words, or paint, or marble. It is the artistic ideals of civilisations that signal where those civilisations hope the human spirit can go, how high it can ascend, into what deeds of astonishment it can flow. Art is the best selves of a people made manifest, one way or another (166).

The problem that is left unaddressed is how to convert the members of a society into sharing this understanding, and Okri's parting gesture in the book is to invite the reader to view his alter ego, Lao, and Mistletoe as inscriptions waiting to be read by 'a world looking in' (Okri 2002, 231). In terms of the logic of the representation that has been unfolded, their experience constitutes a message for those who might discover that they are the addressee. This invitation is reinforced by the dedication of the work, which is 'To You' - that is, to every person who has chosen to traverse In Arcadia.

In some respects, In Arcadia is strikingly similar to certain of its antecedents. Okri’s recognition of the paradox that while reality is imperfectable, the experience of its imperfections generates an impulse to strive towards its perfection, is very close to that of Thomas More in Utopia. His notion of the Arcadian dream providing 'its own heaven, unrealisable in the world, but found within' (120) is similar to the promise 
that the regenerate Adam and Eve receive from the Archangel Michael in Book 12 of Paradise Lost that they will find a 'paradise within' that will compensate them for the loss of Eden, the original earthly paradise (Milton 1957, 587). The idea that art can provide an experience that lifts one above the perturbing limitations and sordidness of the ordinary world is reminiscent of the aestheticism of Matthew Arnold and Walter Pater. Where Okri differs from his Christian-humanist forebears is that the spiritual regeneration set in motion by the experience of Arcadianism is not instrumental to the attainment of a heaven beyond this life-it is of limited value unless it translates into ameliorative intervention in the here and now, because there is no transcendence. More and Milton would have agreed with the first of these propositions, but would have parted company with Okri over the second. Similarly, while Okri's political and social conscience allies him with Arnold's version of aestheticism, it is far too strong to allow him to identify with Pater's doctrine of 'Art for art's sake;' for Okri, art is for the world's sake. Most obviously, the conceptualisation of Arcadianism as a relativised process located in the individual subject as a result of ongoing interpellation that arrives in different ways, and at different times, clearly situates In Arcadia as a distinctively postmodern rewriting of Utopia.

In conclusion, one would say that Okri has attempted to construct a Utopia out of 'the best that has been thought and said' in that genre, but one that has sought to update these notions to accommodate the relativisation and rejection of determinate certainties of postmodernism. In Arcadia aspires to be a truly postmodern utopia, and far from being the incoherent 'ramblings of a stoned sixth former,' succeeds, I believe, in being so.

\section{Reference List}

Adams, T. 2002, 'Grope Springs Eternal,' The Observer [Online]. Available: http://books.guardian.co.uk/reviews/generalfiction/0,,796400.00.html [Accessed 29 Oct. 2004].

Bacon, F. 1909-14 (1526), The New Atlantis. Vol. III, Part 2. The Harvard Classics. New York: P.F. Collier \& Son.

Ball, M. 2002, 'A Review of In Arcadia by Ben Okri,' The Compulsive Reader [Online]. Available http://www.compulsivereader.com/html/modules.php?op=modload\&name=Ne $\underline{\text { ws } \& \text { file }=\text { article } \& \text { sid }=367 \& \text { mode }=\text { thread } \& \text { order }=0 \& \text { thold }=0}$ [Accessed 26 Oct. 2004]. 
Berman, M. 1983, All That is Solid Melts Into Air: The Experience of Modernity, Verso, London.

Brown, H. 2002, Review of In Arcadia, The Independent, cited in 'Ben Okri (1959),' Books and Writers [Online]. Available: http://www.kirjasto.sci.fi/okri.htm [Accessed 20 Nov. 2003].

Collins, J. 1989, Uncommon Cultures: Popular Culture and Post-Modernism, Routledge, New York and London.

Eagleton, T. 1986, 'Capitalism, Modernism and Postmodernism,' in Against the Grain: Essays 1975-1985, Verso, London.

Foucault, M. 1984, 'What is Enlightenment,' in The Essential Works of Michel Foucault 1954-1984, ed. P. Rabinow; Vol. 1: Ethics: Subjectivity and Truth, ed. P. Rabinow, trans. R. Hurley and others, The New Press, New York.

Hickling, A. 2002, 'Tunnel Vision,' The Guardian [Online]. Available: http://books.guardian.co.uk/print/0,3858, 4521773-110738,00.html [Accessed : 20 Nov. 2003.

'In Arcadia by Ben Okri,' [Online], n.d. Available: http://www.calderdale.gov.uk/libraries/books/reviews/bookreviews.jsp?id=741 [Accessed 26 Oct. 2004].

Hutcheon, L. 1989, The Politics of Postmodernism, Routledge, London.

Jameson, F. 1991, Postmodernism, or, The Cultural Logic of Late Capitalism, Verso, London and New York.

Milton, J. 1957 (1667), 'Paradise Lost', in Complete Poems and Major Prose, ed. M. Y. Hughes, The Odyssey Press, Indianapolis, New York.

More, T. 1989 (1516), Utopia, eds George M. Logan \& Robert M. Adams, Cambridge University Press, Cambridge UK.

Okri, B. 1992, The Famished Road, Anchor, 1993.

2002, In Arcadia, Phoenix, London.

Palmer, J. 2002, 'Ben Okri: "Great Art Tries to Get Us to the Place of True Enchantment”,' The Independent [Online]. Available: http://enjoyment.independent.co.uk/books/interviews/story.jsp?story=329903 [Accessed 26 Oct. 2004].

Treglown, J. 2002, 'Past Glories Prove Elusive,' The Spectator [Online]. Available: http://web6.infotrac.galegroup.com/itw/infomark/932/553/55071628w6/purl=r cl_EAIM_0_A92806302\&dyn=4!xrn_5_0_A92806302?sw_aep=otago [Accessed 26 Oct. 2004].

Sannazzaro, J. 1952 (1504), 'Arcadia’, in Opere de Iacopo Sannazzaro, ed. E. Carrara, Turin.

Smith, P. n.d., 'Et in Arcadia Ego' [Online]. Available: http://priory-ofsion.com/psp/id17.html [Accessed 7 Nov. 2004].

Žižek, S. 2001, 'Why Does a Letter Always Arrive at its Destination?', in Enjoy Your Symptom! Routledge, New York and London. 